\title{
KEBERHASILAN RU'YAT AL- HILÂL (Problematika antara Egoisme Figh dan Keberpihakan Ilmu Astronomi)
}

\author{
Achmad Mulyadi \\ (Dosen Tetap Mata Kuliah Ushul Figh pada Jurusan Syariah STAIN Pamekasan, \\ alumni S2 IAIN Sunan Kalijaga Yogyakarta)
}

\begin{abstract}
Abstrak:
Keberhasilan rùyat al-hilâl pada awal Syawwâl 1427 H di Pantai Gebang Bangkalan merupakan fenomena baru yang mengundang polemik dan sangat kontroversial. Kontroversi ini terjadi karena sebagian ilmu hisâb menganggapnya mungkin dilihat (imkân al-ru'yah), sementara sebagian yang lain tidak memungkinkannya (ghayr imkân al-ru`yah), apalagi tidak dilengkapi data-data akurat secara astronomis. Bagaimanakah figh memandangnya dan ilmu astronomis menganalisisnya? Tulisan ini akan mengelaborasi keberhasilan ru'yat al-hilâl tersebut menurut perspektif keduanya. Dalam perspektif figh, keberhasilan ru'yat al-hilâl dapat diterima selama perukyat bersedia disumpah. Sedangkan dalam perspektif ilmu astronomi, fenomena alam, terutama posisi dan gerakan bendabenda langit, dapat diukur dan dianalisis dengan derajat kecermatan yang memuaskan. Karenanya, ilmu ini dapat dijadikan sebagai pedoman dalam penentuan awal bulan Qamariyah. Polemik antara keduanya akan terus berlangsung selama tidak ada "kearifan" dari keduanya menuju penyatuan.
\end{abstract}

Kata Kunci:

astronomis, figh, ru' yat al-hilâl, ru'yah, dan hisâb

\section{Pendahuluan}

Mengawali dan mengakhiri puasa (Ramadlân) merupakan ibadah yang lebih berdimensi ritual-vertikal karena menyangkut kemantapan batin dalam hubungan antara hamba dengan Allâh swt. sehingga lebih terasa terikat dengan ketentuan texbook figh ritual. 
Sedangkan berhari raya idul fitri, walaupun ada kaitan dengan ibadah ritual-vertikal, lebih dikategorikan sebagai ibadah sosialhorizontal ${ }^{1}$ karena menyangkut kemeriahan dan kegembiraan kolektif dalam menyemarakkan hari raya terbesar bagi umat Muslim. Demikian juga memulai puasa Ramadlân dan Syawwâl (idul fitri) masih menyisakan problem krusial yang harus dipecahkan yaitu berkaitan dengan perbedaan metode penentuannya yang secara metodologis terdapat dua metode yang digunakan, yaitu metode ru'yah dan metode hisâb. Metode hisâb menjadikan hasil perhitungan sebagai acuan utama, sedangkan metode ru`yah menjadikan hasil ruyah sebagai pedoman utama dengan menggunakan hasil perhitungan hisâb sebagai alat bantu. ${ }^{2}$

Perbedaan metode di atas lebih diperuncing lagi dengan kriteria penentuan yang berlainan antara kriteria ru'yat al-hilâl dan wujûd al-hilâl. Di Indonesia dua kriteria tersebut digunakan oleh dua ormas besar yaitu NU (kriteria ru'yat al-hilâl) dan Muhammadiyah (kriteria wujûd al-hilâl). Perbedaan tersebut membuka peluang terjadinya penetapan awal bulan Qamariyah. Ini dapat dicontohkan pada perbedaan idul fitri $1427 \mathrm{H}$, di mana Muhammadiyah menetapkan idul fitri jatuh pada tanggal 23 Oktober 2006 berdasarkan kriteria wujûd al-hilâl dengan prinsip wilayat al-hukm, ${ }^{3}$ sedangkan NU menetapkan idul fitri berdasarkan hasil pengamatan menurut kriteria ru'yat al-hilâl, namun karena kriteria hisâb-nya yang umumnya menggunakan ketinggian minimal 2 derajat, maka NU menetapkan idul fitri jatuh tanggal 24 Oktober 2006.

Dalam konteks tersebut, terjadi fenomena menarik, yaitu walaupun menurut sistem ephimeris ketinggian hilâl 0 derajat 30

\footnotetext{
1 Persoalan penetapan awal bulan Qamariyah khususnya Ramadlân, Syawwâl dan Dzulhijjah bukan lagi merupakan problem figh ijtihâdi infirâdi, namun meningkat menjadi fiqh ijtihâdi ijtimâ'i (bercorak sosial kemasyarakatan). Nasaruddin Umar, Memahami Hal Itsbat dalam Perspektif Figh Siyasah, makalah pada Diklat Nasional Pelaksana Rukyat Nahdlatul Ulama tanggal 17-23 Desember 2006 di Masjid Agung Semarang Jawa Tengah.

2 Susiknan Azhari, Ilmu Falak; Teori dan Praktek (Yogyakarta ; Lazuardi, 2001), hlm. 12

3 Wilayat al-hukm adalah negara Indonesia dianggap sebagai satu kesatuan wilayah hukum. Dengan prinsip ini wujûd al-hilâl di sebagian wilayah Indonesia dijadikan dasar penetapan awal bulan untuk seluruh wilayah Indonesia.
} 
detik tanggal 22 Oktober 2006, hilâl berhasil di-ru`yah selama 10 detik oleh Tim Rukyat PCNU Surabaya (KH. Djaelani, H. Achmad Ichsan, H. Abdul Aziz, Catur Hadi, Zakaria dan Nasir) di Pantai Gebang Bangkalan Madura.

Keberhasilan ru'yat al-hilâl tersebut memunculkan pro dan kontra, ada yang menerimanya dan ada pula yang menolaknya. Sidang itsbat Pemerintah menetapkan bahwa hari raya idul fitri jatuh pada tanggal 24 Oktober 2006. Penetapan Pemerintah ini didasarkan pada tidak adanya laporan keberhasilan ru yat al-hilâl yang masuk pada sidang tersebut. ${ }^{4}$ Ini berarti keberhasilan ru'yah di Pantai Gebang Bangkalan masih menyisakan pertanyaan besar, apakah hilâl atau benda yang menyerupai hilâl. Sementara PWNU Jawa Timur menerima dan menganggap laporan tersebut sebagai keberhasilan ru'yah mutlak sehingga perlu mengeluarkan ikhbar penetapan 1 Syawwâl $1427 \mathrm{H}$ yaitu jatuh pada tanggal 23 Oktober 2006. ${ }^{5}$

Realitas di atas menunjukkan bahwa perbedaan tidak hanya ternjadi antara metode hisâb dan rùyah, akan tetapi antar sesama pemegang metode ru'yah pun dapat menimbulkan perbedaan. Munculnya perbedaan respon dan sikap atas satu fenomena keberhasilan rukyattul hilâl yang terkategori ghayr imkân ru'yah tersebut menyebabkan urgensitas tulisan ini khususnya menyangkut status hukum baik perspektif figh-nya maupun pendekatan ilmu astronomisnya.

\section{Penentuan Awal Bulan Qamariyah: Problem Klasik yang Selalu} Aktual

Problematika penentuan awal bulan Qamariyah khususnya menjelang datangnya awal bulan Ramadlân, Syawwâl dan Dzulhijjah yang dijadikan pedoman umat Islâm dalam penentuan ibadah menjadi problem klasik, tetapi selalu aktual. Terkategori klasik karena -secara historis- sejak zaman permulaan Islâm, dan masa perkembangan Islâm selanjutnya para sahabat, tabi'in, ulama dan pakar hukum Islâm selalu menjadikan ketiga awal bulan

${ }^{4}$ Dari 29 titik pengamatan di Indonesia tidak menghasilkan hilâl yang bisa di-ru yah sehingga sehingga sidang itsbat menetapkan istikmal, yaitu menggenapkan bilangan hari bulan Ramadlân.menjadi 30 hari.

${ }^{5}$ Keenam orang yang berhasil melihat hilâl tersebut telah disumpah oleh Pengadilan Agama Bangkalan yang disaksikan oleh Musdi, Moh. Labib, Djihan, dan Achmad Zaini. 
tersebut sebagai pembahasan dalam penetapannya sampai sekarang. Demikian pula problem tersebut menjadi wacana aktual karena berbagai para pakar dari berbagai disiplin ilmu baik ahli hisâb ru yah, astronom, dan ahli lainnya mengkaji dan membicarakan penentuan ketiga awal bulan tersebut sekaligus mencari upaya penyatuannya. Namun demikian, problem tersebut semakin dikaji semakin banyak pula muncul perbedaannya. Problem tersebut jika dilihat dari perspektif sistem dan metode perhitungannya, di Indonesia berkembang dua sistem, yaitu sistem hisâb 'urfi dan sistem hisâb haqî̀î. Dari dua sistem dan metode perhitungan awal bulan qamariyah tersebut, sistem hisâb haqî $\hat{\imath}$ tumbuh dan berkembang sangat pesat. Secara kuantitatif, sistem dan metode hisâb haqî $\hat{\imath}$ berkembang sampai mencapai lebih dari 35 sistem perhitungan.

Sistem hisâb haqîq $\hat{\imath}$ berkembang menjadi tiga sistem, yaitu; hisâb

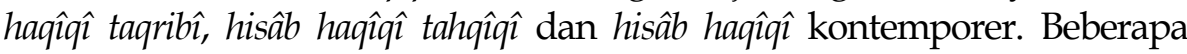
kitab yang menggunakan sistem hisâb haqîqî taqribî seperti sistem Sullam al-Nayirayn, Fath Rauf al-Manan, Tadzkirah al-Ikhwân, Al-Qawâid alFalakiyah, Risâlah Qamarayn, Jadawil al Falakiyah, Hisâb Qath'î, Risâlah Falakiyah, Risâlah Syamsul Hilâl, dan lain-lain. Sedangkan kitab yang menggunakan sistem hisâb haqî̀î tahqî̀î adalah, antara lain, sistem al-Mathla al-Saîd, Manahijul Hamidiyah, al-Khulâshah al-Wafiyah, Muntahâ Nataij Aqwal, Badi'ah al-Mitsal, Hisâb Hakiki, Menara Kudus, Nûr al-Anwâr, Ittifaq Dza al-Bain, dan lain-lain. Demikian pula, beberapa metode yang terkategori hisâb haqîî kontemporer adalah, seperti sistem New Comb, EW. Brown, Islamic Calander, Jean Meuus, Almanac Nautika, Astronomical Almanac, Ephemeris Hisâb Rukyat, Ascript, Astroinfo, Mooncal, Mawâait, Nurul Falak, al-Falakiyah, dan lain-lain. ${ }^{6}$

\footnotetext{
6 Sistem hisâb taqribî menggunakan data asronomi dari daftar asronomis ephemeris, yang disusun oleh Ulugh Beyk yang kemudian dipertajam dengan beberapa koreksi yang sederhana. Penghitungan ketinggian bulan pada saat terbenam matahari pada tanggal terjadinya ijtimâ' adalah dengan mambagi dua selisih waktu saat ijtimâ' dari saat terbenam matahari. Adapun sistem hisâb Tahqîqî mengacu pada data astronomi yang relatif lebih baru yang disitir dari al-Matla' al-Sa'id (Husain Zaid). Dalam menghitung ketinggian bulan, sistem ini sudah menggunakan rumus-rumus ilmu ukur segitiga bola (trigonometri). Sementara sistem hisâb kontemporer disebut juga hisâb tadqî̀î. Sistem ini menggunakan rumus-rumus ilmu ukur segitiga bola dan koreksi-koreksi yang lebih detail yang mengacu pada data astronomi kontemporer, yaitu data yang selalu dikoreksi dengan temuan-temuan astronomis terbaru. Sistem ini dikembangkan oleh lembaga-lembaga astronomi seperti Planetarium, BMG, dan Observatorium BOSSCHA.
} 
Selain itu, masih banyak varian-varian di masyarakat yang menganut kepercayaan dan keyakinan yang berbeda-beda dalam penetapan awal bulan. Di antara masyarakat berbeda-beda dalam menjadikan ru yah sebagai pedoman, yaitu ru' yah bi al-fi'li, ru yah regional, ru' yah global, imkân ru' yah 2 derajat, imkân ru'yah di seluruh Indonesia, imkân ru yah MABIMS, dan imkân ru'yah Istambul. Demikian juga terdapat masyarakat yang menggunakan perhitungan 'urfi, perhitungan Aboge, dan perhitungan Asapon. Akan tetapi juga tidak dapat diingkari terdapat masyarakat yang berpedoman pada penetapan Arab Saudi, negara-negara Muslim, atau hanya pada kenyakinan dan perhitungan tokoh dan kyai panutan.

Perbedaan-perbedaan di atas menjadi sumber munculnya perbedaan dalam berhari raya idul fitri. Namun demikian, perbedaan yang terjadi pada penentuan idul fitri $1427 \mathrm{H}$ tidak hanya perbedaan antara ahli hisâb $b^{7}$ dan ahli ru yah ${ }^{8}$, akan tetapi perbedaan terjadi antara sesama ahli

7 Perbedaan dalam penentuan awal Ramadlân dan Syawwâl sering terjadi pada umat Muslim. Yang biasa dijadikan kambing hitam adalah perbedaan hukum figh dalam memahami sejumlah Hadîts, misalnya: "Janganlah [memulai] puasa Ramadlân hingga terlihat bulan dan janganlah berbuka (mengakhiri puasa Ramadhan) hingga terlihat bulan pula. Maka jika pandangan kalian terhalang awan, sempurnakan bilangan bulan [Ramadhan hingga] 30 hari". (HR. Bukhari \& Muslim). Pada intinya perbedaan ini menimbulkan dua madzhab, yang secara sederhana bisa disebut madzhab ru`yah (yang mendasarkan awal bulan pada terlihatnya bulan sabit) dan madzhab hisâb (yang mendasarkan awal Ramadlân dan Syawwâl pada penghitungan mutlak). Madzhab rùyah yang berpedoman pada pendapat jumhûr ulamâ' berpegang pada nash Hadits tersebut. Memang yang diwajibkan adalah berpuasanya, bukan ru'yah-nya. Namun karena perintah ru'yah itu berkaitan dengan suatu hal yang bersifat wajib, maka perintah itu pun menjadi wajib. Sedang madzhab hisâb menafsirkan rùyah tidak sekedar bermakna ru'yah bi al- 'ayn (dengan pandangan mata) namun juga ru'yah bi al-'aql (dengan akal, dan berarti dengan penghitungan).

${ }^{8}$ Ru yat al-hilâl adalah melihat bulan sabit setelah ijtimâ' dan setelah wujûd di atas ufuk. Ijtimâ' atau konyungsi adalah saat bulan dan matahari memiliki bujur ekliptika yang sama. Ekliptika adalah sistem koordinat langit untuk menggambarkan posisi matahari, bulan, dan planet-planet dekat. Peristiwa ijtimâ' terjadi serentak sekali setiap satu periode bulan mengelilingi bumi (sinodis). Dengan demikian pada saat ijtimâ', ada wilayah di muka bumi yang sedang pagi, siang, sore, atau malam hari. Sedangkan hilâl hanya bisa dilihat di sore hari, bila tingginya sudah cukup, sehingga pada saat matahari terbenam, bulan masih di atas ufuk (Barat), sehingga ada bagiannya yang memantulkan cahaya matahari ke bumi, sebelum akhirnya bulan terbenam menyusul matahari. Inilah bulan sabit yang ditunggu-tunggu penampakannya. Oleh karena itu, meskipun ijtimâ' terjadi serentak, namun peristiwa yang hilâl bisa di-ru'yah tidaklah serentak, melainkan terikat oleh aspek astronomi 
ru'yah. Perbedaan hari raya idul fitri ini mengakibatkan munculnya perdebatan antara ahli figh dan ahli ru'yah. Para ahli figh beranggapan bahwa penetapan awal bulan Ramadlân, Syawwâl dan Dzulhijjah termasuk masalah fiqh ijtihâdî infirâdî yang dapat dilakukan oleh setiap individu muslim. Atas dasar inilah, hasil ru'yah seseorang hanya berlaku bagi dirinya dan orang-orang yang mempercayainya. Dengan demikian, barometer penentuan awal dan akhir bulan Qamariyah adalah melihat hilâl apalagi kesaksian melihat hilâl tersebut disahkan oleh hakim. ${ }^{9}$ Sedangkan para ahli ru yah berpendapat bahwa di zaman moderen ini untuk mendapatkan keyakinan atas laporan ru`yah perlu didukung dengan data hisâb yang tingkat akurasinya tinggi dan pertimbangan astronomis yang meyakinkan (pengamatan empirik posisi hilâl). Dengan demikian, hasil ru'yah seseorang perlu dianalisis kesaksiannya tidak hanya menurut perspektif figh-nya akan tetapi juga dipertimbangkan dari sisi akurasi data perhitungan dan posisi astronomis hilâlnya. ${ }^{10}$

\section{Komputasi (Hisâb): Alat Bantu Ru'yat al-hilâl}

Keberhasilan ru yah awal bulan tentu tidak terlepas dari sistem hisâb yang digunakan. Penggunaan sistem ini menjadi niscaya

(posisi bujur dan lintang pengamat) sekaligus aspek geografis (perbedaan zone waktu) nya. Secara astrogeografi, daerah yang lebih Barat (dihitung dari Batas Tanggal Internasional) akan menyaksikan bulan yang lebih tua, sehingga peluang ru yat al-hilâl pada hari yang sama akan lebih besar. Dalam pelaksanaannya, waktu ru'yah adalah amat pendek, yakni kurang dari satu jam setelah matahari terbenam. Maka jika tersiar suatu berita ru'yat al-hilâl yang terjadi sebelum matahari terbenam di tempat tersebut, atau setelah tengah malam, atau bahkan sebelum ijtimâ' adalah wajib ditolak. Secara teknis, pelaksanaan ru'yah mudah dilakukan oleh siapa pun, asalkan dilaksanakan saat cuaca sedang cerah (tidak mendung), topografi memungkinkan (tidak ada penghalang ke ufuk Barat), pengamat bermata sehat, serta pengamat terbiasa memperhatikan kondisi benda-benda langit. Syarat syar'î untuk pengamat ru' yah adalah 'aql, baligh dan 'adl (tidak terkenal gemar berbohong). Tentu saja ini berlaku pada masyarakat yang memang tahu apa yang disebut hilâl.

${ }^{9}$ Al-Malibarî, Fath al-Mu'în, (Ttp: Maktabah Muhammad al-Nabhan wa awlâdih, t.th.), hlm. 54-55. Bandingkan dengan Muslim, Shahîh Muslim, Juz I (Ttp: Dâr al-Fikr, t.th.), hlm. 480-482.

10 Perbedaan ukuran tinggi hilâl dipengaruhi oleh faktor perbedaan sistem, alat yang digunakan dan faktor hasib. Secara astronomis, tinggi hilâl mencapai imkân al- ru yah jika memenuhi kriteria tertentu yaitu tinggi hilâl 2 derajat dan umur bulan 8 jam sesudah ijtimâ'. Sebaliknya, jika tidak memenuhi kriteria tersebut, maka terkategri ghayr imkân al-ru’yah. 
karena hisâb diposisikan sebagai alat bantu keberhasilan pelaksanaan ru'yah. Sistem hisâb, sebagai ilmu yang dibangun di atas hasil penyelidikan empirik terhadap posisi dan gerakan benda-benda langit, terus berkembang selaras dengan hasil-hasil penyelidikan itu sendiri. Trend perkembangan tersebut secara umum mengarah kepada lahirnya produk hitungan dengan derajat akurasi yang semakin tajam. Di sisi lain perkembangan tersebut secara tak terelakkan membawa konsekwensi lahirnya berbagai sistem hisâb dengan akurasi yang bervariasi, sehingga muncul kategorisasi yang

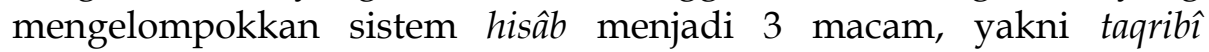

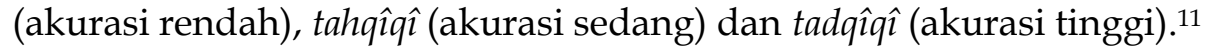

Sistem hisâb taqribî menggunakan data astronomi dari daftar ephimeris yang disusun oleh Ulugh Beyk (w. $854 \mathrm{M}$ ) yang kemudian dipertajam dengan beberapa koreksi yang sederhana. Dalam menghitung ketinggian bulan pada saat terbenam Matahari pada tanggal terjadinya ijtimấ, sistem taqribî melakukannya dengan membagi dua selisih waktu saat ijtimâ' dari saat terbenam matahari. Tentu saja dengan cara seperti itu produk hitungannya menjadi bersifat "kurang-lebih". Sistem hisâb yang dikategorikan sistem ini, yaitu Sullam al-Nayyirain karya KH. Muhammad Mansur bin Abdul Hamid (Jakarta), Fath al-Rauf al-Mannan karya KH. Abu Hamdan Abdul Jalil (Kudus), dan Qawâid Falakiyah karya Abd al-Fatah at-Turki (Mesir). Sedangkan sistem tahqîqî mengacu pada data astronomi yang relatif lebih baru yang disitir oleh al-Matla' al-Sa't̂d karya Husayn Zaid (Mesir). Dalam menghitung ketinggian bulan, sistem ini sudah menggunakan ilmu ukur segitiga bola (trigonometri) sehingga hasilnya lebih cermat. Sistem hisâb yang dipandang masuk kategori ini antara lain al-Khulasha al-Wafiyah karya KH. Zubair Umar al-Jailani (Salatiga). Hisâb Haqî̀̂ิ karya KRT Wardan Dipodiningrat (Yogyakarta), dan Ittifâq Dzât al-Bain karya KH Kamil Hayyan (Gresik). Adapun sistem hisâb tadqî̀̂, di samping menggunakan ilmu ukur segitiga bola dan koreksi yang lebih detail, mengacu pada data astronomi kontemporer, yaitu data yang selalu dikoreksi dengan temuan-temuan terbaru. Sistem ini dikembangkan oleh lembaga-

\footnotetext{
${ }^{11}$ Abd Salam Nawawi, "Algoritma Hisab Ephemeris" makalah Diklat Nasional Pelaksana Rukya NU tanggal 26 Dzulqa'dah-2 Dzulhijjah 1427 H/ 17-23 Desember 2006 di Masjid Agung Semarang Jawa Tengah.
} 
lembaga astronomi seperti Planitarium, Badan Meteorologi dan Geofisika serta Observatorium Bosscha ITB. Sistem hisâb yang masuk kategori ini antara lain New Comb, Jean Meeus, Nautical al-Manac, dan Ephimeris Hisab Rukyat Departemen Agama RI.

Di Indonesia, semua sistem hisâb tersebut dipelajari dan digunakan secara riil sebagai acuan perhitungan. Karena itu, timbulnya produk hitungan yang berbeda-beda menjadi sesuatu yang tak terelakkan, bahkan dengan perbedaan yang sangat mencolok yang dari sudut ilmu pasti sulit untuk ditoleransi.

Salah satu contoh pada pelaksanaan ru`yah awal Syawwâl 1427 $\mathrm{H}$, terdapat beberapa hasil perhitungan yang berbeda. Di antara hasil perhitungan tersebut, sistem yang digunakan oleh para perukyat adalah hasil hisâb kitab Fath al-Rauf al-Mannan, Risâlah al-Qamarayn dan Sullam al-Nayyirayn. Dari ketiga hasil hisâb tersebut menunjukkan bahwa ijtimâ' akhir bulan Ramadlân $1427 \mathrm{H}$ jatuh pada Ahad pahing, tanggal 22 Oktober 2006 pukul 11.39 menit dengan ketinggian hilâl 3 derajat 10 menit. Dari ketinggian hilâl di atas lama hilâl di atas ufuk mencapai 12 menit 41 detik serta posisi hilâl berada di sebelah selatan titik barat dengan posisi hilâl miring ke selatan. Namun demikian, apabila dilihat dari sistem hisâb yang berkembang di Indonesia, ketiga sistem tersebut memiliki tingkat akurasi yang rendah karena termasuk kategori taqribî. Sementara menurut sistem ephimeris ketinggian hilâl hanya 0 derajat 30 detik sehingga lama hilâl di atas ufuk selama 2 menit.

\section{Ru'yat al-hilâl : Fenomena Baru yang Kontroversial}

$R u^{\prime}$ yah merupakan salah satu metode penentuan awal bulan hijriyah. Semula hanya metode ini yang dipegangi oleh umat Islâm sebagai dasar penentuan awal bulan Qamariyah khususnya awal bulan Ramadlân, Syawwâl dan Dzulhijjah sebagaimana diajarkan Rasulullah saw. Namun ketika ilmu hisâb masuk dalam kalangan umat Islâm pada abad 8 masehi di masa Dinasti Abbasiyah, maka mulai berkembang pemikiran untuk menggunakan hisâb bagi penentuan awal bulan qamariyah. Dua metode tersebut (ru'yah dan hisâb) kemudian sama-sama menjadi pegangan penentuan awal bulan

Qamariyah hanya saja memunculkan perbedaan prinsip pengambilannya. Ada yang memeganginya secara mandiri (hisâb 
tanpa ru'yah) dan adapula yang mempedomaninya hanya sebagai alat bantu (ru'yah dengan alat bantu hisâb). Prinsip yang terakhir ini menjadi metode yang dipegangi oleh kalangan umat Nahdlatul Ulama, karena prinsip inilah pelaksanaan ru'yah dilakukan

Mereka meyakini bahwa hilâl berada di sebelah selatan matahari sehingga matahari itu yang menjadi patokan untuk meru'yah. Kemudian dengan tanpa diduga hilâl kelihatan. Hilâl nampak tiga tahap. Tahap pertama terlihat kira-kira magrib baru berjalan sekitar 3-5 menit dilanjutkan dengan tahap kedua dan akhirnya muncul lagi di tahap terakhir sekitar 8-10 menit setelah terbenam matahari. Rombongan yang melihat langsung mengumandangkan takbir sebagai tanda keberhasilan mereka melihat hilâl.

Pelaksanaan ru'yah dengan hasil komputasi yang berbeda, yang akhirnya disinyalir berhasil adalah pelaksanaan ru`yah ru`yah awal Syawwâl 1427 H. Keberhasilan melihat hilâl tersebut merupakan sejarah baru bagi pelakasanaan ru'yah selama ini, karena derajat ketinggian paling rendah yang berhasil di-ru'yah adalah 5 derajat menurut hisâb Fath al-Rauf al-Manan dan 2 derajat menurut ephimeris. Perasaan senang yang berlebihan dan kejadian keberhasilan ru'yah yang tiba-tiba membuat peru'yah tidak sadar akan waktu. Yang mereka ingat adalah mereka berhasil melihat hilâl setelah terbenam matahari. Peristiwa keberhasilan me-ru yah tidak terekam dalam catatan waktu sehingga penunjukan jam secara sembarangan yaitu jam 17.38.

Peristiwa keberhasilan ru'yah tersebut, kemudian berusaha dilaporkan ke Pengurus Cabang Nahdlatul Ulama Surabaya. Namun sayang, tidak bersambung. Akhirnya informasi keberhasilan ru`yah disampaikan ke salah satu pengurus PWNU Jawa Timur yaitu KH. Miftahul Ahyar. Keberhasilan ru yah ini akhirnya tersebar dimanamana termasuk di seluruh media elektronik di Surabaya. Begitu juga menjadi wacana perdebatan yang amat panas antara kemungkinan dan kemustahilan melihat hilâl. Keberhasilan ini pun berusaha dilaporkan ke PBNU oleh pengurus PWNU Jawa Timur, akan tetapi tidak diterima dengan alasan keterlambatan laporan. ${ }^{12}$ Akhirnya

12 Laporan Lajnah Falakiyah kepada PBNU tentang penyelenggaraan ru'yah untuk idul fitri $1427 \mathrm{H}$, hlm. 8 . 
PWNU Jawa Timur mengeluarkan keputusan untuk memberikan ikhbar kepada warga NU di Jawa Timur. Inilah awal terjadinya perbedaan untuk melaksanakan hari raya idul fitri sebagai tanda mengakhiri bulan puasa dan mengawali bulan Syawwâl $1427 \mathrm{H}$.

Demikian juga di kabupaten Bangkalan sendiri, pemerintah setempat atas rekomendasi dan fatwa MUI setempat mengeluarkan keputusan untuk menerima keberhasilan ru yah pantai Gebang, sebagaimana penuturan ketua majelis itsbat Pengadilan Agama Bangkalan, Bapak H. Afandi Zaini. Walaupun demikian, keberhasilan ru'yah di Kabupaten Bangkalan memunculkan wacana antara yang menerima dan menolaknya. Mereka yang menerima karena posisi hilâl masuk dalam kategori tidak mungkin di-ru'yah (ghayr imkân alrukyah) dan mereka yang menerimanya karena perukyatnya sudah disumpah oleh Pengadilan Agama yang memiliki wewenang untuk mengambil sumpah.

Keberhasilan ru'yah harus dipertanggungjawabkan. Salah satu bentuk pertanggungjawabannya adalah bersedia untuk disumpah. Diantara alasan mereka yang menerima keberhasilan ru`yah di Pantai Gebang Bangkalan adalah karena para perukyat bersedia disumpah. Pelaksanaan ru'yat al-hilâl tersebut dilakukan oleh tim dan sebagian masyarakat Gebang, Tim tersebut terdiri dari enam perukyat dan kesemuanya bersedia untuk disumpah. Pemeriksaan persidangan Pengadilan Agama Bangkalan yang memeriksa dan mengitsbatkan ru`yat al-hilâl yang berlangsung di Tempat Observasi Bulan (TOB) di Desa Gebang Kecamatan Bangkalan dan Kabupaten Bangkalan dilakukan oleh empat hakim Pengadilan Agama Bangkalan. Empat hakim tersebut adalah Drs H. A. Afandi Zaini, SH. (Hakim Ketua Majelis), Drs. Akhmad Abdul Hadi (Hakim Anggota), Drs. Mohammad Ali Rido (Hakim Anggota) dan H. Moh. Hosen, SH. (Panitera Pengganti). ${ }^{13}$ Sebelum proses pengambilan sumpah dan itsbat dilangsungkan, Majelis Hakim memberikan 8 pertanyaan kepada dan langsung dijawab oleh enam musyahadah tersebut. Setelah pemeriksaan dilakukan kemudian persidangan pengambilan sumpah dibuka oleh Ketua Majelis Hakim dan dinyatakan terbuka

13 Sesuai dengan Penetapan Ketua Pengadilan Agama Bangkalan Nomor: PA.m/31/Hk.03.2/493/2008 tentang Penunjukan Majelis Persidangan untuk memeriksa dan mengitsbat kesaksian ru’yat al-hilâl tertanggal 13 September 2006. 
untuk umum. Secara formal, proses pemerikasaan tersebut dapat diterima, namun demikian, satu hal yang lepas dari pemeriksaan para Mejelis Istbat adalah tentang pengeksekusian ulang posisi hilâl yang di-ru'yah, di arah mana dan berapa derajat dari titik barat dan matahari. Karena itu, fenomena tersebut merupakan fenomena baru yang tidak lepas dari polemik dan menjadi sangat kontroversial.

\section{Keberhasilan Ru'yah: Egoisme Fiqh versus Keberpihakan Astonomis}

Keberhasilan ru'yah di Pantai Gebang Bangkalan yang menimbulkan kontroversi perlu dikaji secara fiqhis dan astronomis. Dua kajian itulah yang menyebabkan perbedaan pendapat. Jika kita mendalaminya melalui pendekatan figh, laksana kita berenang di pusat persimpangan arus. Telaga figh kita di seputar masalah ini sudah dipenuhi kontroversi yang tajam.

Madzhab Syâfi'î saja menyuguhkan kepada kita paling tidak ada tiga versi pendapat.

1. Pendapat Imâm al-Ramlî dan al-Khatîb al-Syarbini yang menutup rapat masuknya pendekatan hisâb dalam penentuan awal bulan Islâm (Iâ 'ibrah li qawol al-hussâb )14.

2. Pendapat Imâm al-Subkî, al-'Abbadî dan al-Qalyubî yang menolak ru'yah jika dimustahilkan oleh hisâb. ${ }^{15}$

3. Pendapat Imâm Ibnu Hajar al-Haithâmî yang setuju rùyah ditolak bila semua ilmuwan hisâb sepakat menafikannya. Namun jika mereka tidak begitu, maka ru'yah tidak dapat ditolak. ${ }^{16}$

Sedangkan dalam madzhab Hanafî dan madzhab Mâlikî, menurut qawl yang $m u^{\prime}$ tamad, yang menjadi syarat wajib puasa dan

\footnotetext{
14 Abû Bakr Utsmân bin Muhammad Syattâ al-Bakr, Hasyiyah al-Thâlibîn, juz 2, (Beirut: Dâr al-Kutub al-Ilmiyyah, t.th.), hlm. 216. Lebih tegas Imâm Ramlî berpendapat bahwa ru'yah harus diterima karena ru'yah (syahadah) memiliki kedudukan yang sama dengan yakin. Lihat, al-Ramlî, Fatâwâ al-Ramlî (Beirut: Dâr alMa'rifah, 1988), hlm. 358.

15 Ibid; lihat juga Syihâb al-Dîn al-Qalyûbî dan Syihâb al-Dîn Umairah, Hasyiyah alQalyubî wa 'Umayrah 'ala Minhaj al-Thâlibîn, juz 2. (Mesir: Dâr Ihyâ'al-Kutub alIlmiyah, t.th.) hlm. 49.

16 Ibnu Hajar al-Haythâmî, Tuhfat al-Muhtaj, Juz 3 (Beirut: Dâr al-Kutub al-'Ilmiyah, 1994), hlm. 38.
} 
beridul fitri adalah ru'yah, bukan pada pendapat ahli hisâb. Berbeda dengan Imâm Mâlik, al-Qarafi berpendapat bahwa boleh berpegang pada hisâb dalam penetapan hilâl. ${ }^{17}$

Sedangkan teknis penetapan bulan Ramadlân dan Syawwâl atas dasar ru' yah pun dipenuhi kontroversi, yaitu tentang banyaknya saksi yang dapat diterima. Imâm Mâlik mensyaratkan dua orang saksi sebagai syarat minimal. Imâm Syâfi'î dari riwayat Muzanî membedakan jumlah saksi antara awal Ramadlân (dengan satu orang saksi) dan Syawwâl (dengan dua orang saksi). Sedang Abû Hanîfah membedakannya berdasarkan kondisi cuaca, jika mendung cukup satu orang saksi (awal Ramadhân) dan dua orang saksi (awal Syawwâl) serta jika cerah harus dari kesaksian banyak orang. Dari ketiga pendapat tersebut mengisyaratkan bahwa setiap kesaksian (apalagi banyak) sudah dapat dijadikan dasar untuk menetapkan awal bulan khususnya bulan Ramadlân dan Syawwâl. Perspektif inilah yang banyak dipegangi mereka yang menerima keberhasilan ru yah tanpa memasukkan pertimbangan secara astronomis. Karena itu, jika hanya ini yang dipegangi, maka figh dipandang sangat egois dan dianggap sebagai satu-satu perspektif yang dapat digunakan. Kalau kita masuk ke pusaran arus kontroversi figh tersebut, boleh jadi kita akan berputar di tempat. Maksud hati hendak bertolak meninggalkan sudut ikhtilâf dengan karsa mencari " titik temu ", tapi apa daya perjalanan berujung kembali pada sudut yang sama.

Allâh swt. adalah Dzât Yang Maha Mencipta dan Maha Mengatur. Dia menciptakan semua makhluk dan mengaturnya menurut hukum yang dibuat-Nya sendiri. Hukum-hukum-Nya dapat dipilah, secara garis besar, ke dalam dua bagian, yaitu sunnatullâh dan dînullâh. Sunnatullâh mengatur dan berlaku untuk alam semesta ( makrokosmos, alam gedhe) dan alam manusia ( mikrokosmos, alam cilik). Hukum ini tidak diwahyukan, tetapi dihampar dalam bentangan realitas alam semesta dan alam manusia, yang semuanya tunduk patuh kepadanya dengan sukarela maupun terpaksa. Hukum ini obyektif, pasti, dan tetap. Karena tidak diwahyukan, pengetahuan manusia tentang hukum sunnatullâh diperoleh melalui pengamatan dan percobaan. Hasilnya berupa berbagai disiplin "llmu dunia" atau

17 al-Qarafi, Ikhlâsh al-Nawî, Juz. 1 (Beirut: Dâr al-Ihyâ' al-Turâts al-'Arabî, 1994), hlm. 358. 
yang lazim kita sebut "ilmu umum", yang terdiri atas, antara lain, ilmu kimia, fisika, biologi, kedokteran, astronomi (hisâb), dan sebagainya. Ilmu-ilmu dunia ini derajat kebenarannya bergantung pada seberapa akurat ia didukung oleh bukti nyata atau oleh realitas empiris-obyektif.

Dînullâh secara khusus mengatur alam manusia (mikrokosmos, alam cilik), yaitu tentang bagaimana manusia harus berperilaku terhadap pencipta-Nya, dirinya sendiri, sesamanya, dan alam lingkungannya. Hukum dînullâh ini bersifat "subyektif" ( setiap orang mempunyai kemerdekaan untuk memilih antara tunduk kepadanya atau tidak ), "tidak pasti" ( akibat hukum yang ditimbulkannya bisa berbeda-beda tergantung pada faktor-faktor yang mengitarinya ), dan "tidak tetap" ( hukumnya bisa berubah karena 'illat atau karena perubahan zaman dan tempat ).

Hukum ini diwahyukan, di mana untuk umat Muhammad terangkum dalam al-Qur'ân dan al-Sunnah. Karena itu, pengetahuan tentang hukum dînullâh diperoleh manusia melalui pengkajian atau penelaahan dalil-dalil naql (teks-teks wahyu). Hasilnya mengejewantah dalam berbagai disiplin "ilmu agama ", antara lain ilmu Tauhid, Tasawuf, Tafsir, Hadits, Figh, dan sebagainya. Derajat kebenaran ilmu-ilmu agama ini bergantung pada seberapa akurat ia didukung oleh dalil-dalil naql yang sifatnya legal-formal.

Persoalan dalam kalender Islâm yang sedang kita bicarakan ini, yakni penentuan awal bulan, adalah persoalan yang bertemali baik dengan hukum dînullâh maupun dengan hukum sunnatulllâh. Karena itu dalam membicarakan persoalan tersebut kedua jenis hukum Allâh itu harus dilibatkan sesuai dengan proporsinya.

Sebagai dînullâh, Islâm telah menggariskan 5 (lima) rambu prinsip berkenaan dengan kalender syar'î-nya. Pertama, bahwa sistemnya adalah sistem kalender bulan. Kedua, bahwa pergantian siklus hari atau tanggalnya mengacu pada momen terbenamnya matahari. Ketiga, bahwa pergantian siklus bulannya mengacu pada fenomena kemunculan hilâl. Keempat, bahwa pergantian siklus tahunnya mengacu pada berlalunya masa 12 bulan. Kelima, bahwa 
cara penyusunannya "diciptakan" menggunakan perhitungan (hisâb). ${ }^{18}$

Kita memfokuskan pada rambu kelima, karena rambu ini, seperti tampak di awal pembicaraan, adalah sesuatu yang paling menjadi pusaran kontroversi. Sunnatullâh tentang pergerakan bulan yang teratur dan terukur diakui oleh siapa pun (baca: disepakati) amat kondusif bagi terwujudnya irâdah Ilâhiyyah yang digariskan dalam rambu kelima di atas, yaitu cita penyusunan kalender Islâm dengan pendekatan ilmu hisâb (perhitungan). Tetapi, sebagai ilmu dunia, ilmu hisâb tidak dapat digali dari hukum dînullâh yang dirangkai dalam teks al-Qur'an dan al-Sunnah sebagaimana ilmu figh, melainkan harus dilacak dan ditelusuri dari hamparan hukum sunnatullâh di alam semesta yang mengatur pergerakan benda-benda langit, khususnya bulan, bumi, dan matahari. Jadi, untuk menuju kelahiran ilmu hisâb guna penyusunan kalender Islâm dibutuhkan kerja proses pengumpulan data empirik yang akurat tentang ihwal pergerakan benda-benda langit, khususnya bulan, bumi dan matahari dari perspektif ruang dan waktu. Satu-satunya instrumen dalam kerja proses ini adalah observasi atau penginderaan atau $r u^{\prime}$ yah bi al-fi'I.

Di sini dapat ditegaskan bahwa ru'yah bi al-fi'l adalah "ibu" yang dari rahimnya kelak akan lahir "anak" yang bernama ilmu hisâb. Namun, menuju kondisi yang memungkinkan untuk itu, sang ibu harus melewati proses kehamilan yang memakan waktu lama. Hal ini disebabkan:

1. Karena obyek yang harus diobservasi sang ibu letaknya amat sangat jauh dari bumi.

2. Untuk kecermatan observasi yang dilakukannya, sang ibu membutuhkan sarana pendukung yang pengadaan dan peningkatan akurasinya bergantung pada penemuan ilmiah di bidang teknologi teleskopik sehingga membutuhkan waktu yang panjang juga.

3. Pergerakan benda-benda langit yang harus diobservasi sang ibu berlangsung dalam siklus waktu yang panjang dan dalam bentangan ruang yang sangat luas.

18 Kelima rambu pinsip tentang kalender Islâm ini diderivasi dari surah al-Baqarah (2): 189; surah al-Tawbah (9): 36-37, surat Yûnus (10): 5; sûrat al-Isrâ' (17): 12; dan surat al-Rahmân (55): 5. 
Selagi ilmu hisâb "masih dalam kandungan", kebutuhan umat Muslim pada pengetahuan mengenai kalender Islâm dipenuhi dengan memanfaatkan hasil temuan sporadis sang ibu (ru'yah bi al$f^{\prime} l$ ), yaitu temuan tentang kemunculan hilâl atau ketidakmunculannya. Kondisi seperti ini terjadi pada zaman Nabî saw, zaman di mana umat Muslim masih dililit oleh problem keummian. Kondisi umat Islâm di zaman Nabî saw. yang kebudayaannya masih sangat bersahaja itu diungkapkan sendiri oleh beliau melalui sabdanya : "Sesungguhnya kita adalah umat yang ummi. Kita tidak bisa menulis dan tidak bisa menghitung. ${ }^{19}$ Satu bulan itu sekian, dan sekian ", beliau menekuk ibu jari pada yang ketiga, "dan satu bulan itu sekian, dan sekian ", yakni sempurna tiga puluh hari (HR Muslim) ${ }^{20}$. Beliau selaku pemangku al-Qur'ân, tentu menyadari betul mengenai irâdah Ilâhiyyah yang menciptakan penyusunan kalender Islâm dengan pendekatan hisâb. Tetapi kondisi aktual umat pada zaman beliau memang masih "jauh panggang dari api" untuk dapat merealisasikannya.

Mengacu pada hasil temuan sporadis ru'yah bi al-fi'l memang menyimpan sejumlah kelemahan. Hilâl yang diobservasi, walaupun sudah muncul, boleh jadi tidak terdeteksi karena terhalang mendung atau lainnya, arah/fokus pandangan perukyat tidak tepat, dan ada problem pada mata perukyat. Selain itu, bisa juga hilâl yang belum muncul dikira muncul karena kekeliruan perukyat dalam menyimpulkan dan bisa juga perukyat melakukan rekayasa (mengada-ada) dengan melaporkan bahwa hilâl sudah muncul, padahal belum, atau sebaliknya.

Dalam kondisi yang serba terbatas, Nabî saw berusaha meminimalkan segi-segi kelemahan temuan sporadis ru'yah bi al-fi'I itu dengan melacak akurasi empiriknya melalui dua jalur. Pertama,

19 Maksudnya ialah bahwa sesungguhnya segenap orang Arab adalah umat yang buta huruf, tidak punya pengetahuan tentang tulis menulis, walaupun pernyataan ini tidak menafikan kenyataan adanya sebagian dari mereka yang bisa menulis seperti Abd Allâh ibn 'Amir, Mu'awiyah, 'Alî, dan Zayd ibn Tsabit, dan tidak mempunyai pengetahuan tentang perhitungan bintang dan lintasannya. Atau maksudnya adalah mereka tidak bisa menulis dan menghitung dengan baik. Lihat Manshûr 'Alî Nasif, al-Tâj al-Jâmi' li al-Ushûl, Juz II (Kairo: Maktabah al-Mujallad al-'Arabî, t.th.), hlm. 54 dan 'Ali ibn Sulthân Muhammad al-Qarî, Miqat al-Mafâtih, Juz IV (Beirut: Dâr alRasyad al-Hadîtsah, t.th.), hlm. 465

${ }^{20}$ Muslim, Shahîh Muslim, Juz 1 (Bandung: Dahlan, t.th.), hlm. 437 
jalur obyektif melalui kontrol "umur bulan" yaitu bahwa ru' yah harus terjadi pada penghujung hari ke-29. Kedua, jalur subyektif melalui kontrol "kejujuran perukyat", yaitu dengan menjadikan iman kepada Allâh dan Rasûl sebagai indikator pengukur. Meskipun dengan dua jalur kontrol tersebut peluang terjadinya kekeliruan dalam penentuan awal bulan Islâm masih cukup lebar, tetapi spirit akurasi empirik yang divariasikan Nabî saw mesti dilihat sebagai penyemangat kaum Muslim angkatan berikutnya untuk terus berupaya mewujudkan penentuan awal bulan Islâm dengan kecermatan yang lebih tajam. Dengan perspektif inilah selanjutnya bisa dianalisis semua fakta tentang praktik penentuan awal bulan Islâm pada zaman Nabî saw. Tegasnya, fakta yang diwarisi dari zaman Nabî saw, bukan cita penentuan awal bulan yang sudah ideal dan final, melainkan yang masih terbuka untuk terus dipertajam akurasinya dan ditingkatkan.

Melalui kerja panjang yang memakan waktu ratusan tahun, akumulasi hasil ru'yah bi al-fi'l telah mengejewantah dalam wujud data astronomi yang akurat tentang posisi benda-benda langit. Di pihak lain, kondisi ummi sudah lama lenyap dari panggung kehidupan kaum Muslim. Para ahli hisâb umat Muslim kini bertebaran dimana-mana. Ormas-ormas Islâm di Indonesia rata-rata sudah mewadahi mereka ke dalam lembaga-lembaga hisâb ru yah. Mereka, dengan mendayagunakan akumulasi data hasil ru'yah bi al$f^{\prime} l$, bukan lagi hanya bisa menghitung posisi dan saat kemunculan hilâl, tetapi juga saat ijtimâ' (konjungsi), saat gerhana, saat awal waktu shalat, arah bayang-bayang kiblat, dan sebagainya, dengan derajat kecermatan yang memuaskan. Kecuali tentang saat kemunculan hilâl untuk penentuan awal bulan Islâm, hasil kerja mereka sudah diapresiasi dengan semestinya oleh umat Islâm.

Ketika penguasaan umat Islâm terhadap ilmu dunia yang berkenaan dengan sunnatullâh tentang pergerakan benda-benda langit (ilmu hisâb) kemajuannya sudah sedemikian rupa seperti digambarkan di atas, agaknya tidak lagi pada tempatnya bila umat Muslim terus saja mengandalkan secara apa adanya hasil ru'yah bi alfi'l yang dilakukan secara sporadis. Umat Muslim sudah tidak lagi berada dalam lilitan kondisi "ummi" seperti umat Muslim di zaman Nabî saw. Karena itu umat Muslim harus bergeser ke tahapan berikutnya yang muqtadla al-hâl dengan kondisi keinginannya. 
Dalam kaitan ini, alternatifnya, menurut penulis, ada dua. Pertama, jika dianggap bahwa era untuk merealisasikan irâdah Ilâhiyyah tentang penyusunan kalender Islâm dengan pendekatan hisâb masih belum waktunya, dalam arti hasil ru'yah bi al-fi'l yang sporadis itu tadi hendak didayagunakan, maka kontrol terhadap akurasi hasilnya harus dipertajam dengan kontrol "kelahiran hilâl". Artinya, pada zaman ini pelacakan akurasi hasil ru'yah tidak lagi berhenti hanya pada kriteria hari ke-29, seperti pada zaman Nabî saw, tetapi harus ditambah dengan kriteria bahwa hilâl yang menjadi obyek ru'yah itu sudah berpeluang lahir. Kontrol kelahiran hilâl ini jelas tidak berkaitan dengan otoritas ilmu agama (figh), melainkan sepenuhnya berada dalam wilayah otoritas ilmu dunia (astronomi). Karenanya, yang dibutuhkan adalah subyek-perukyat yang tidak hanya jujur, tetapi juga cermat, supaya hasil ru`yah-nya selaras dengan sunnatullâh.

Kedua, jika dipandang bahwa tingkat perkembangan ilmu hisâb dewasa ini sudah sangat memadai untuk merealisasikan irâdah Ilâhiyyah tentang penyusunan kalender Islâm dengan pendekatan ilmu hisâb, maka kegiatan ru'yah bi al-fi'I yang sporadis itu dialihkan pada kegiatan observasi astronomi yang lebih sistematik, terukur, dan terdokumentasi. Selanjutnya, umat Muslim mesti mulai mengarahkan sebagian angkatan mudanya pada minat studi yang mengambil fokus pada elaborasi sunnatullâh tentang benda-benda langit dan ruang angkasa, di mana kaum Muslim pada masa lalu pernah berjaya di bidang itu.

Secara astronomis, jika melihat pada keberhasilan ru`yah di Pantai Gebang Bangkalan yaitu bahwa jeda waktu antara bulan tenggelam dengan matahari tenggelam kurang dari 3 menit. ${ }^{21}$ Mungkinkah dengan jeda waktu yang kurang dari 3 menit keberadaan hilâl dapat dikenali oleh mata manusia? Ketika matahari tersebut tenggelam, semburat cahaya matahari masih sangat terang dan obyek langit seperti bintang atau planet lainnya dapat dikenali 510 menit sejak matahari tenggelam dengan ketinggian yang relatif

21 Data dan sistem yang dipergunakan untuk menganalisis adalah menggunakan perhitungan Ephemeris, Mawaqit 2001 (Khalid) dan MoonCalc v.6 (Monzur Ahmeed). Penggunaan sistem ini berdasarkan kesetaraan yang dapat disebut identik. Keakurasiannya dapat dilihat perbandingannya dengan hasil pengamatan yang dilakukan tanggal 17 Oktober 2006. 
tinggi sehingga tidaklah mungkin dapat mengenali keberadaan hilâl yang waktu tenggelamnya berbeda hanya 3 menit.

Pada saat matahari tenggelam posisi hilâl tidak lebih dari 15 menit busur. Dengan meninjau bahwa diameter sudut matahari dan bulan sebesar 30 menit busur, maka 15 menit busur menggambarkan ketinggian sebesar setengah diameter sudut bulan ataupun matahari. Jika ketinggian bulan tersebut dihitung dari pusat penampang lingkaran bulan, maka ketika matahari disebut tenggelam daerah sabit bulan itu sudah berada tepat bersinggungan dengan horison atau ufuk yang sangat tidak mungkin untuk dikenali dengan mata. Di samping itu, iluminasi atau fraksi bulan yang memantulkan cahaya ke arah bumi yang hanya $0.10 \%(100 \%=$ purnama $)$ pantulannya tidak dapat dikenali di tengah-tengah terangnya cahaya matahari. Di balik itu cahaya matahari yang dipantulkan oleh bulan tersebut juga mengalami penyerapan dan penghamburan oleh atmosfir bumi, sehingga tidaklah mungkin mengenali keberadaan sabit hilâl sekali pun kondisi langit horison barat tidak berawan. Karenanya, sangat mungkin bahwa apa yang dikenali sebagai hilâl tersebut adalah obyek lain yang disangka sebagai hilâl.22

\section{Penutup}

Problematika penentuan awal bulan Qamariyah khususnya menjelang datangnya awal bulan Ramadlân, Syawwâl dan Dzulhijjah yang dijadikan pedoman umat Muslim dalam penentuan ibadah menjadi problem klasik, tetapi selalu aktual. Problematikanya tidak hanya berputar pada sekitar antara dua metode yang berbeda, akan tetapi dalam satu metode yang samapun tidak dapat terlepas dari perbedaan dalam penentuannya. Sesama metode rùyah, misalnya, keberhasilan rùyat al-hilâl menjadi perdebatan menarik sekitar apakah betul obyek yang dilihat adalah hilâl. Walaupun demikian, dalam perspektif figh, setiap kesaksian sudah dapat dijadikan dasar untuk menetapkan awal bulan khususnya bulan Ramadlân dan Syawwôal, apalagi saksi-perukyat bersedia disumpah maka keberhasilan ru yah-nya dapat diterima, tanpa memasukkan pertimbangan secara astronomis. Sementara dalam ilmu astronomi fenomena alam apa pun hanya dapat dianalisis dengan terapi astronomis karena fenomena alam adalah statis

\footnotetext{
22 Hendro Setyanto, Kesaksian hilal Awal Syawal 1427 H, artikel dalam laporan Lajnah Falakiyah PBNU, November 2006, hlm.12-13.
} 
dan tidak mudah berubah. Polemikini tidak akan berhenti selama figh semakin egois dan ilmu astronomis tetap berpihak pada teori-teorinya tanpa ada upaya penyatuan keduanya. Wallâh a'lam bi al-Shawab.

\section{Daftar Pustaka}

Azhari, Susiknan. Ilmu Falak; Teori dan Praktek . Yogyakarta: Lazuardi, 2001

Bakr, Abû Bakr Utsmân bin Muhammad Syattâ al-. Hasyiyah alThâlibîn, Juz 2. Beirut: Dâr al-Kutub al-Ilmiyyah, t.th.

Haythâmî, Ibnu Hajar al-. Tuhfat al-Muhtaj, Juz 3. Beirut: Dâr al-Kutub al-'Ilmiyah, 1994.

Malibarî, al-. Fath al-Mu'în. Ttp: Maktabah Muhammad al-Nabhan wa awlâdih, t.th.

Muslim, Shahîh Muslim, Juz 1. Bandung: Dahlan, t.th.

Nasif, Manshûr 'Alî. al-Tâj al-Jâmi' li al-Ushûl, Juz II. Kairo: Maktabah al-Mujallad al-'Arabî, t.th.

Nawawi, Abd Salam. "Algoritma Hisab Ephemeris" makalah Diklat Nasional Pelaksana Rukya NU tanggal 26 Dzulqa'dah-2 Dzulhijjah 1427 H/ 17-23 Desember 2006 di Masjid Agung Semarang Jawa Tengah.

Qalyûbî, Syihâb al-Dîn al- dan Syihâb al-Dîn Umairah, Hasyiyah alQalyubî wa 'Umayrah 'ala Minhaj al-Thâlibîn, Juz 2. Mesir: Dâr Ihyâ'al-Kutub al-Ilmiyah, t.th.

Qarafi, al-. Ikhlâsh al-Nawî, Juz. 1. Beirut: Dâr al-Ihyâ' al-Turâts al'Arabî, 1994.

Qârî, 'Ali ibn Sulthân Muhammad al-. Miqat al-Mafâtih, Juz IV. Beirut: Dar al-Rasyad al-Hadîtsah, t.th. 
Ramlî, al-. Fatâwâ al-Ramlî. Beirut: Dâr al-Ma'rifah, 1988.

Setyanto, Hendro. Kesaksian hilal Awal Syawal 1427 H, artikel dalam laporan Lajnah Falakiyah PBNU, November 2006.

Umar, Nasaruddin. Memahami Hal Itsbat dalam Perspektif Fiqh Siyasah, makalah pada Diklat Nasional Pelaksana Rukyat Nahdlatul Ulama tanggal 17-23 Desember 2006 di Masjid Agung Semarang Jawa Tengah. 